\title{
Examination of Paramolar Tubercles in Turkish Population Using Cone Beam Computed Tomography
}

\author{
Estudio de los Tuberculos Paramolares en una Población Turca \\ Mediante Tomografía Computarizada de Haz Cónico
}

Magrur Kazak ; Gizem Colakoglu²; Mehmet Ali Elcin²; Esra Somturk² \& Solen Gunal ${ }^{3}$

KAZAK, M.; COLAKOGLU, G.; ELCIN, M. A.; SOMTURK, E. \& GUNAL, S. Examination of paramolar tubercles in Turkish population using cone beam computed tomography. Int. J. Morphol., 35(4):1416-1421, 2017.

SUMMARY: Paramolar tubercle (PT) is an additional cusp occuring on buccal surface of both upper and lower permanent molars. PT is also known as parastyle when tubercle is present in upper molars, as protostylid when tubercle is present in lower molars. The aim of this study was to evaluate prevalence of PTs in Turkish population with cone beam computed tomography (CBCT). Presence of PT in molar teeth were evaluated retrospectively using CBCT images of 210 patients (102 male, 108 female) between 18-77 years old. A total of 909 teeth were analyzed. Because of various reasons some teeth were excluded and final analyze was done with 653 teeth. Prevalence of PT was found as $2.76 \%$ (18 out of 653). Highest frequency of PT was detected 5 in \#27, 4 in \#17, 2 in \#48 among all molar teeth respectively. In two cases; 2 PTs were on the same tooth, bilateral PT was found only in one case. PT was undetected on upper first molars. Prevalence of PTs on permanent molars is a rare phenomenon in the studied population. Use of CBCT in such anatomic variations will provide valuable and detailed information during treatment modalities. Since this pilot study represents Turkish subpopulation, comprehensive studies with increased number of cases should be undertaken to clarify the prevalence of paramolars in Turkish population. Advanced imaging techniques like CBCT will be more helpful in understanding and detecting exact morphological and anatomical variations of PTs during treatment modalities.

KEY WORDS: Cone beam computed tomography; CBCT images; Developmental dental anomaly; Molar tooth; Paramolar tubercle.

\section{INTRODUCTION}

The extra tubercle occuring on the buccal surface of upper and lower premolar and molar teeth is called paramolar tubercle (PT) (Bolk, 1914; Dahlberg, 1950). This tubercle usually presents unilaterally in permanent dentition (Kustaloglu, 1962) and occurs in low frequencies (Nirmala et al., 2013). The term 'paramolar tubercle' was first described by Bolk in 1916 (Bolk, 1916). PT was defined as 'parastyle' when it is located on upper molars and as 'protostylid' when it is located on lower molars (Dahlberg, 1945; Dahlberg, 1950).

Parastyle is usually observed on the mesiobuccal cusp (paracone) and rarely on the distobuccal cusp (metacone) of the upper molars. It may also occur on the buccal surface of premolars. Additionally, double cusp formation is highly rare on the maxillary molars (Kustaloglu).
Protostylid is an additional enamel elevation, characteristically located on the mesial half of the buccal surface of the lower molars that arises mesio-occlusally from the gingival end of the buccal groove (Dahlberg, 1950; Bolk, 1916; Dahlberg, 1963).

These additional cusps seem to arise during the morphogenesis process (Turner et al., 2004; Gaspersic, 1993). Parastyle is considered as a cingulum derivative, expressed on the paracone, arising from an accessory enamel knot at the tooth surface (Scott \& Turner, 1997; Rodriguez et al., 2006). Protostylid is derived from the anterior portion of the buccal cingulum. Its particular character and location seem to indicate that these tubercules are residual evidences in man's dentition of the past (Dahlberg, 1950).

\footnotetext{
${ }^{1}$ Bezmialem Vakif University Dentistry Faculty, Restorative Dentistry Department, Istanbul, Turkey.

${ }^{2}$ Istanbul Aydin University Dentistry Faculty, Oral and Dentomaxillofacial Radiology Department, Istanbul, Turkey.

${ }^{3}$ Istanbul Altinbas University Dentistry Faculty, Restorative Dentistry Department, Istanbul, Turkey.
} 
PTs can vary in shape and size from a simple protuberance to a well-developed lobulated cusp which mimics as a fused supernumerary tooth. The lobulated cusp may contain a pulp tissue associated with a root that may be either undeveloped or fully formed (Bolk, 1916; Magalee \& Kramer, 1984). The root canals of these additional tubercles are generally in connection with other root canals; but rarely they can be detected seperately (Friedman et al., 1986; Zidan \& el-Deeb, 1991).

These anatomical variations may influence the treatment modality and its outcomes. External anatomy of these tubercles is well known but there is limited information about the internal anatomy (root anatomy, root canals and relationship with other roots). Knowledge of PTs' internal anatomy is crucial in diagnosis and treatment plan of many dental disciplines (Magalee \& Kramer; Zidan \& el-Deeb; Ohishi et al., 1999). Two dimensional imaging techniques such as periapical, occlusal or panoramic radiographies are often incapable of revealing the true size, location and root canal configuration if present. Due to the compression of three dimensional structure into two dimensional image, superposition of anatomical structures and distortion, three dimensional imaging aids the diagnosis (Patel et al., 2007).

Computed tomography (CT) may allow imaging of anatomy more precisely. However, because of high radiation dose and cost, it has limitations (Scarfe \& Farman, 2008). Recently, with the introduction of ConeBeam Computed Tomography (CBCT) in dentomaxillofacial imaging, it has enabled three dimensional visualization of anatomical structures with the advantages of easier image acquisition, lower radiation dose, cost and rapid scannig time compared to CT (Scarfe \& Farman; White \& Pharoah, 2009).

Earlier studies showed varying prevalance of PT (Kustaloglu; Ooshima et al., 1996). Yet, the data on the presence of PT in some populations are limited. In that regard, morphological studies play an essential role in evaluating the frequencies of PT.

In clinical practice, PT is essential due to the variations in the external morphology of the tooth which is unavoidable to have variations in the root canal complex and is a challenge to the endodontist during diagnosis and root canal treatment (Malagnino et al., 1997). Also $\mathrm{PT}$ is of great importance in the periodontal treatment for understanding the complex anatomy of tooth and its relationship with the surrounding structure and may also cause dental caries depending on the susceptible region for plaque accumulation. Additionally it is necessary to consider this tubercle during orthodontic banding and rubber dam application (Paras Mull \& Manjunath, 2013).

To our best knowledge, the prevalence of PT in Turkish population has not been investigated yet. Thus the aim of this study was to estimate the prevalence of PT in Turkish population using CBCT and to emphasize the importance of PT in dental practice.

\section{MATERIAL AND METHOD}

Samples. A total of 210 patients (102 male and 108 female patients between age of $18-77$, mean age 40,75 years) were chosen by analyzing the records of Oral and Dentomaxillofacial Radiology Department retrospectively between January 2014 to February 2015.

Informed consent was obtained from all patients before taking CBCT images and the study protocol was approved by the ethical review of Istanbul Aydin University (02.09.2015 and No: 052).

Radiographic techniques. CBCT scans were obtained using 3D Accuitomo 170 (J. Morita, Kyoto, Japan). Scan parameteres were $90 \mathrm{kV}, 5 \mathrm{~mA}$ and $30.8 \mathrm{sec}$ using 250 $\mu \mathrm{m}$ voxel size with 140x100 cm field of view (FOV).

Evaluation of the image. All CBCT scans were analyzed by two oral and dentomaxillofacial radiologists (GC, MAE) retrospectively according to the presence or absence of PT on permanent molar teeth. Coronal, axial, sagittal and cross-sectional planes with $1 \mathrm{~mm}$ slice thickness and interval were reconstructed using i-Dixel 2.0 software (Version 3.1.62; Xoran Technologies, Ann Arbor, USA) (Fig. 1). 3D reconstructions were performed as necessary. CBCT scans were evaluated on 30 inch flat panel (DELL U3014 Ultrasharp, USA) with a resolution of 2560x1600 pixel in a dark room. Only high quality scans were included.

Of the 909 molar teeth, 85 impacted teeth, 171 teeth with big caries, restorations and crowns were excluded. Finally, 653 molar teeth were analyzed in the study.

Statistical analysis. The collected data was entered into a personal computer and statistical analysis was performed using SPSS for Windows (SPSS Inc., v22.0, Chicago, IL, USA). Data was evaluated according to descriptive statistics, presented as frequencies (n) and percentages (\%). 


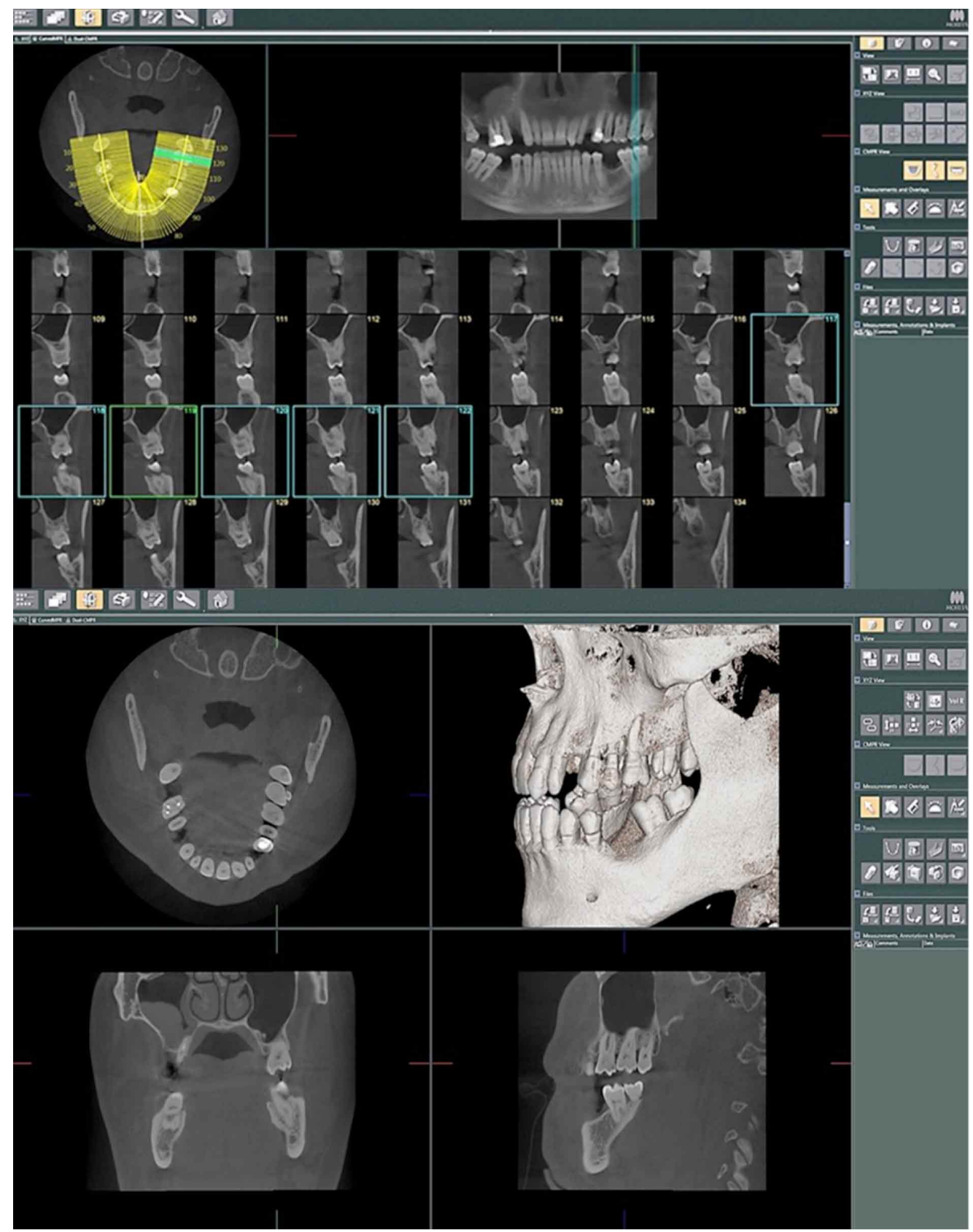

Fig. 1. Evaluation of CBCT scans of permanent molars according to PTs on coronal, axial, sagittal, crosssectional planes and $3 \mathrm{D}$ views.

\section{RESULTS}

Of the analyzed teeth, $2.76 \%$ (n:18) showed paramolar tubercle. Teeth 17, 27 and 48 were showed the highest frequency of PT which were detected as 5, 4 and 2 respectively (Table I).
No PT was detected on the maxillary first molars. Only in one case, bilateral PT (\#36 and \#46) was observed (Fig. 2). In two cases, 2 PTs on the same tooth (\#17, \#27) were detected (Fig. 3), (Table I).

The percentages of PTs were $4.63 \%$ in females and $9.80 \%$ in males. (Fig. 4). 


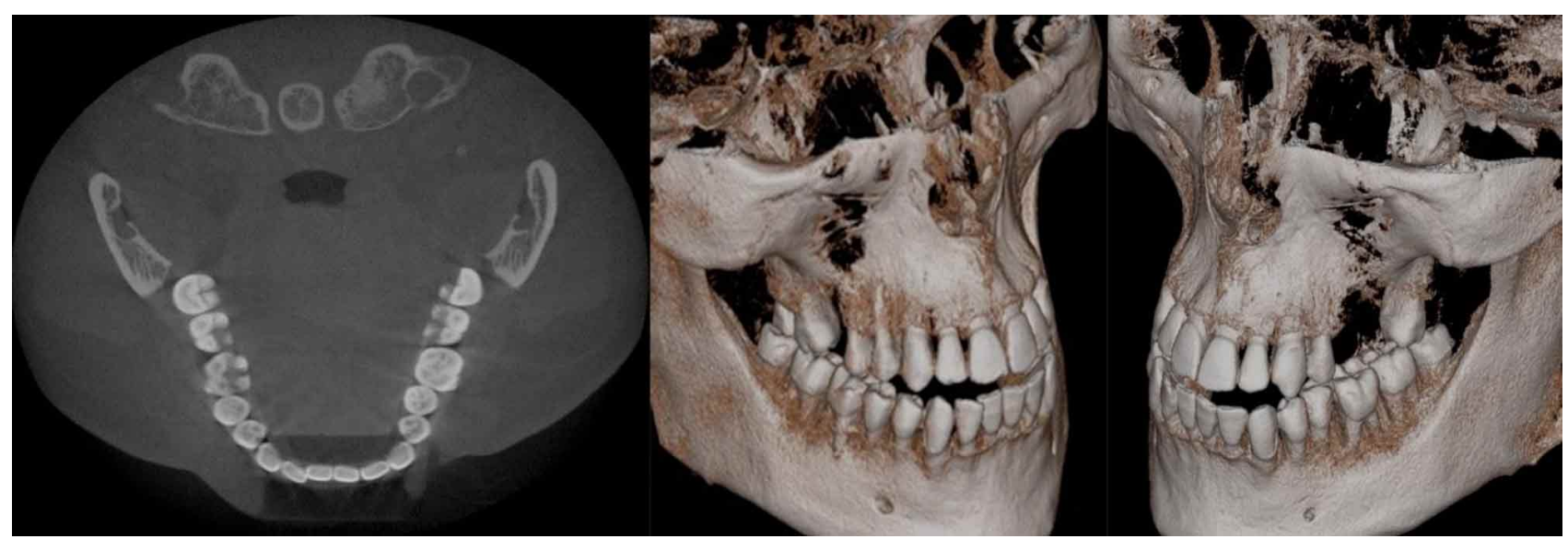

Fig. 2. Axial and 3D view of bilateral PT on mandibular first molar teeth.

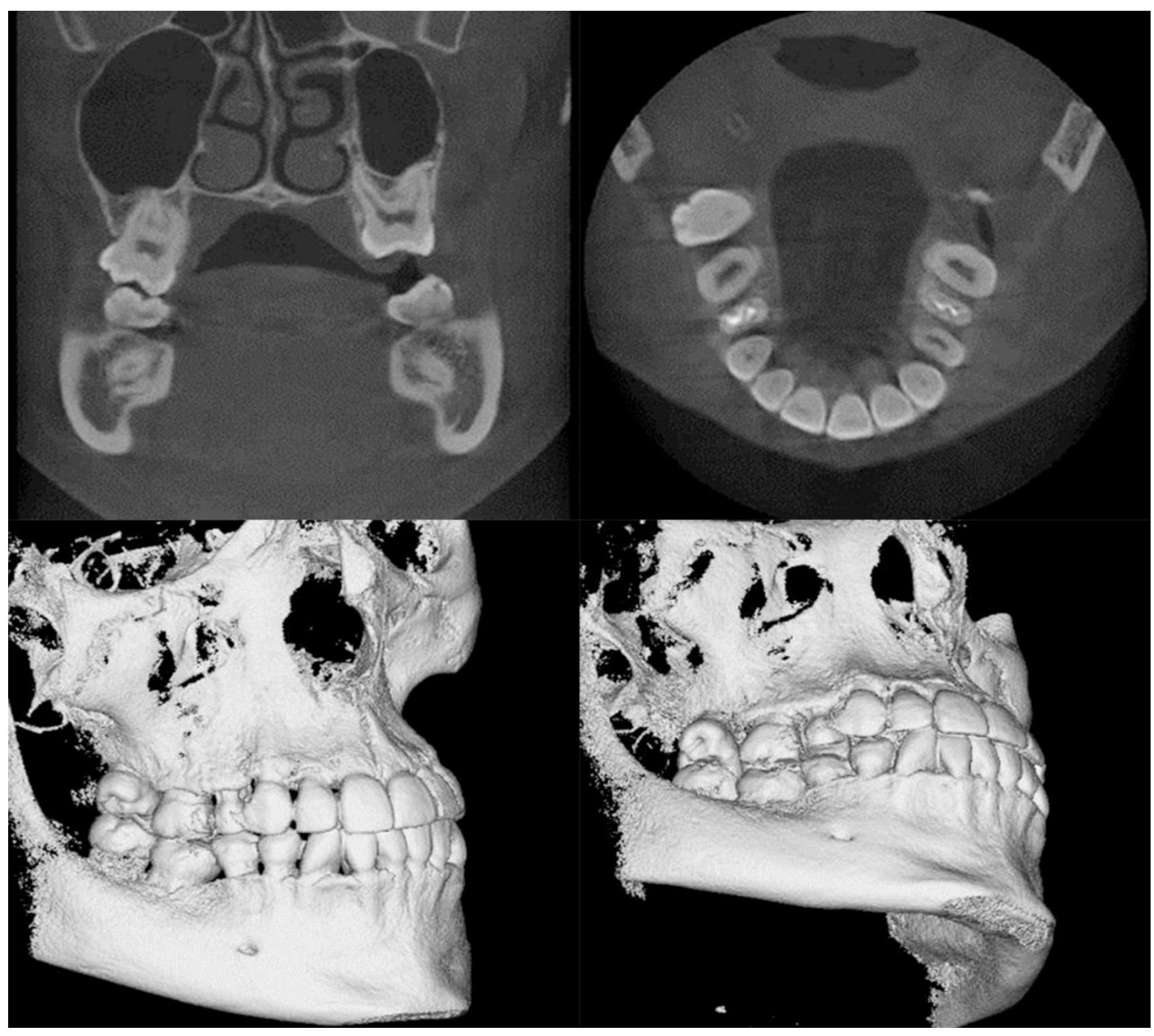

Fig. 3. Coronal, axial and 3D views of two PTs on the same tooth (\#17). 


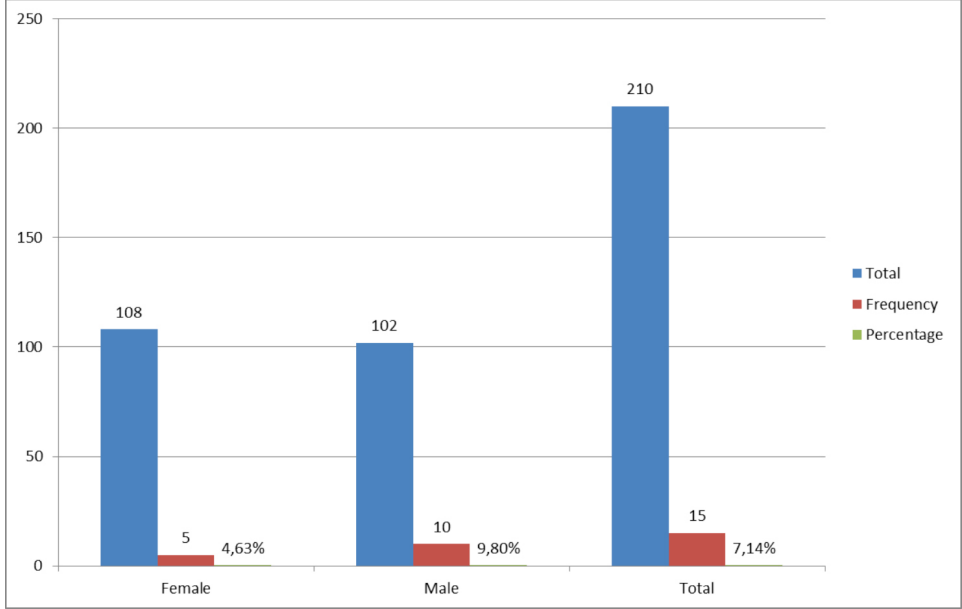

Fig. 4. The distribution of PTs among sexes.
Table I. The number and prevalance of PTs among molar teeth.

\begin{tabular}{lccc}
\hline & \multicolumn{3}{c}{ NUMBER OF PT } \\
& & Single & Double \\
\hline PARASTYLE & 16 & & \\
& 17 & 3 & 1 \\
& 18 & 1 & \\
& 26 & & \\
PROTOSTYLID & 27 & 4 & 1 \\
& 28 & 1 & \\
& 36 & 1 & \\
& 37 & 1 & \\
& 38 & 1 & \\
& 46 & 1 & \\
& 47 & 1 & \\
& 48 & 2 & \\
\hline
\end{tabular}

N Total: 653, NParamolar:18, Prevalance: 2,76\%

\section{DISCUSSION}

Metric and non-metric analysis of dental structures have long been studied over the last century (Nayak et al., 2013). PTs are recognized as non-metric dental traits that can be easily observed and documented. Due to the high taxonomic value, they have been used to estimate biological relationship among diverse populations (Scott \& Turner).

Ethnic and racial background may play an important role in the occurrence of PTs (Nayak et al.). A number of studies have reported the incidence of PT. According to these studies, the incidence of PT varies from 0 to $0.1 \%$ in maxillary first molar teeth, 0.4 to $2.8 \%$ in maxillary second molar teeth and 0 to $4.7 \%$ in maxillary third molar teeth (Kustaloglu; Ooshima et al.). Due to the low occurence of these tubercles, it is possible for the clinicians to underestimate the complications related to the anatomy of PTs which make treatments challenging in many dental disciplines.

Paramolars were reported to be rare among Africans, Europeans and their grandsons in America while more common in a group of native Americans (Dahlberg, 1950). No cusp formation was observed among whites, Negroes, Filipinos and Hawaiians. On the contrary, Indians showed a higher occurence when compared to other populations (Kustaloglu).

No study has investigated the occurence of PTs in Turkish population. Therefore, this study has been a pioneer study evaluating the prevalence of PTs in Turkish population.

In this study, the prevalence of PT was found as $2.76 \%$, which was in accordance with the results of Rodriguez \& Moreno (2006) and Kustaloglu. Rodriguez \& Moreno described paramolars as a low-frequency trait. Kustaloglu, indicated the prevalence of PT in range of $0.06-7.7 \%$.

This study showed the highest frequency of PTs in teeth maxillary second molars. Interestingly PT was undetected on the maxillary first molars. Bolk (1916), reported PTs occured on second and third permanent molars but never on first permanent molars. Furthermore, Dahlberg (1945), defined both maxillary and mandibulary first permanent molars were less variable in pattern and had smaller coefficients of variability than the second and third molars. This stability might be a reason for the lower occurance of PTs on the first molars.

Kustaloglu indicated that PTs tend to occur unilaterally in permanent dentition. In this study, bilateral PT was found in only one case. Therefore, it can be concluded that, these tubercles arise unilaterally.

As a very rare occurrence, double PTs were seen on the same tooth in this study that supported Kustaloglu.

Due to low prevalence of PTs, internal anatomy of this structure has not been examined exactly. There is still limited information about its root and root canal morphology. This tubercle may contain pulp tissue and root canals of PTs may be connected with other canals. This anatomical variations can create treatment challenges and affect the prognosis. Some researchers evaluated the internal anatomy of PTs using three dimensional imaging techniques like CT (Ohisi et al., 1999), spiral CT (Nayak et al.) and CBCT (Ikeda \& Suda, 2012; Jain et al., 2014; Desai et al., 2014; Sekerci \& Özcan, 2015). Even though root and root canal morphology were not assessed in this study, CBCT images evaluted the occurrence of PTs in order to eliminate the problems such as superposition of dental structures and distortion encountered with two dimensional imaging techniques. 


\section{CONCLUSIONS}

The prevalence of PTs on permanent molars is a rare phenomenon in Turkish population. Advanced imaging techniques like $\mathrm{CBCT}$ will be more helpful in understanding and detecting exact morphological and anatomical variations of PTs. The use of CBCT in such anatomic variations will provide valuable and detailed information during treatment modalities.

This pilot study is about Turkish subpopulation. Therefore, comprehensive studies with increased number of cases should be undertaken to clarify the prevalence of paramolars in Turkish population.

KAZAK, M.; COLAKOGLU, G.; ELCIN, M. A.; SOMTURK, E. \& GUNAL, S. Estudio de los tuberculos paramolares en una población turca mediante tomografía computarizada de haz cónico. Int. J. Morphol., 35(4):1416-1421, 2017.

RESUMEN: El tubérculo paramolar (TP) es una cúspide adicional que está en la superficie vestibular de los molares permanentes superiores e inferiores. El objetivo de este estudio fue evaluar la predisposición de TP en la población turca con tomografía computarizada de haz cónico (TCHC). Presencia de TP en dientes molares se evaluaron retrospectivamente utilizando imágenes de tomografia de 210 pacientes (102 hombres, 108 mujeres) entre 18-77 años de edad. Se analizó un total de 909 dientes. Por varias razones, algunos dientes fueron excluídos y el análisis final se realizó con 653 dientes. Prevalencia de PTP se encontró en el 2,76 \% (18 dientes de 653). La frecuencia más alta de TP se detectó: 5 en \# 27, 4 en \# 17, 2 en \# 48, entre todos los dientes molares, respectivamente. En dos casos, 2 de los TP fueron observados en el mismo diente; TP bilateral sólo se encontró en un caso. El TP no fue detectado en los primeros molares superiores. La prevalencia de TP en los molares permanentes es un fenómeno poco frecuente en la población estudiada. El uso de la TCHC en tales variaciones anatómicas, proporcionará información valiosa y detallada para definir la aplicación de diferentes modalidades de tratamiento. Dado que este estudio piloto representa a una subpoblación turca, estudios exhaustivos con un mayor número de casos deben llevarse a cabo para determinar la prevalencia en la población turca total. Técnicas avanzadas de imagen como TCHC serán más útiles para detectar variaciones morfológicas y anatómicas exactas de TP durante diversas modalidades de tratamiento.

PALABRAS CLAVE: Tomografía computarizada de haz cónico; Imágenes TCHC; Desarrollo Anomalía dental; Diente molar; Tubérculo paramolar.

\section{REFERENCES}

Bolk, L. Problems of human dentition. Am. J. Anat., 19(1):91-148, 1916. Bolk, L. Supernumerary teeth in molar region in man. Dent. Cosm., 56:15467, 1914.

Dahlberg, A. A. Analysis of the American Indian Dentition. In: Brothwell, D. R. (Ed.). Dental Anthropology. Oxford, Pergamon, 1963. pp.149-77.

Dahlberg, A. A. The evolutionary significance of the protostylid. Am. J. Phys. Anthropol., 8(1):15-25, 1950.

Dahlberg, A. A. The paramolar tubercle (Bolk). Am. J. Phys. Anthropol., 3(1):97-103, 1945.

Desai, V. D.; Gaurav, I.; Das, S. \& Sunil Kumar, M. V. Paramolar complex The microdental variations: Case series with review of literature. Ann. Bioanthropol., 2(2):65-73, 2014.
Friedman, S.; Stabholz, A. \& Rotstein, I. Endodontic managment of molars with developmental anomalies. Int. Endod. J., 19(6):267-76, 1986.

Gaspersic, D. Morphology of the most common form of protostylid on human lower molars. J. Anat., 182(Pt. 3):429-31, 1993.

Ikeda, H. \& Suda, H. Iatrogenic pulp exposure in paramolar tubercles carries the risk of pulp or tooth loss. I. J. D. C. R., 2(5):66-72, 2012.

Jain, P.; Ananthanarayan, K.; Ballal, S. \& Natanasabapathy, V. Endodontic management of maxillary second molars fused with paramolar tubercles diagnosed by cone beam computed tomography - two case reports. $J$. Dent. (Tehran), 11(6):726-32, 2014.

Kustaloglu, O. A. Paramolar structures of the upper dentition. J. Dent. Res., 41(1):75-83, 1962.

Magalee, R. E. \& Kramer, S. The paramolar tubercle: a morphological anomaly with clinical considerations. N. Y. State Dent. J., 50:564-66, 1984.

Malagnino, V.; Gallottini, L. \& Passariello, P. Some unusual clinical cases on root anatomy of permanent maxillary molars. J. Endod., 23(2):127-8, 1997.

Nayak, G., Shetty, S. \& Singh, I. Paramolar tubercle: A diversity in canal configuration identified with the aid of spiral computed tomography. Eur. J. Dent., 7(1):139-44, 2013.

Nirmala, S. V. S. G.; Gaddam, K. R.; Vimaladevi, P. \& Nuvvula, S. Protostylid: A case series. Contemp. Clin. Dent., 4(3):349-52, 2013.

Ohishi, K.; Ohishi, M.; Takahashi, A.; Kido, J.; Uemura, S. \& Nagata, T. Examination of the roots of paramolar tubercles with computed tomography: report of 3 cases. Oral Surg. Oral Med. Oral Pathol. Oral Radiol. Endod., 88(4):479-83, 1999.

Ooshima, T.; Ishida, R.; Mishima, K. \& Sobue, S. The prevalence of developmental anomalies of teeth and their association with tooth size in the primary and permanent dentitions of 1650 Japanese children. Int. J. Paediatr. Dent., 6(2):87-94, 1996.

Paras Mull, J. \& Manjunath, M. K. Paramolar tubercle in endodontics: An overview, case report and specimen study. J. P. F. A., 27(4):124-8, 2013.

Patel, S.; Dawood, A.; Ford, T. P \& Whaites, E. The potential applications of cone beam computed tomography in the management of endodontic problems. Int. Endod. J., 40(10):818-30, 2007.

Rodriguez, C. \& Moreno, F. Paramolar tubercle in the left maxillary second premolar: a case report. Dent. Anthropol., 19:65-9, 2006.

Scarfe, W. C. \& Farman, A. G. What is cone-beam CT and how does it work? Dent. Clin. North Am., 52(4):707-30, 2008.

Scott, G. R. \& Turner, C. G. Description and Classification of Permanent Crown and Root Traits. In: Scott, G. R. \& Turner, C. G. $2^{\text {nd }}$ (Eds.). The Antropology of Modern Human Teeth-Dental Morphology and its Variationin Recent Human Populations. Cambridge, Cambridge University Press, 1997. pp.15-69.

Sekerci, A. E. \& Özcan, G. Paramolar Tüberkül: Klinik Önemleri ile Birlikte Bes Olgu Sunumu, Türkiye Klinikleri. J. Dental Sci. Cases, 1(3):199203, 2015 .

Turner, R. A. \& Harris, E. F. Maxillary second premolars with paramolar tubercles. Dent. Anthropol., 17:75-8, 2004.

White, S. C. \& Pharoah, M. J. Oral Radiology: Principles and Interpretation. $6^{\text {th }}$ ed. St. Louis, Mosby/Elsevier, 2009.

Zidan, O. \& el-Deeb, M. Restorative and endodontic management of an anomalous mandibular molar. Quintessence Int., 22(3):189-92,1991.

\section{Corresponding author: \\ Dr. Magrur Kazak}

Bezmialem Vakif University Dentistry Faculty

Restorative Dentistry Department

Istanbul

TURKEY

E-mail: mkazak@bezmalien.edu.tr

Received: 16-09-2016

Accepted: 05-05-2017 